\title{
Early Identification of Putative Zygotic Seedlings in Citrus Crosses between 'Morita unshiu' (Citrus. unshiu Marc.) and 'Ponkan' (C. reticulata Blanco) Using RAPD and SRAP
}

\author{
Su Hyun Yun ${ }^{1+}$, Young Sun Moon ${ }^{2+}$, Seong Beom Jin ${ }^{3}$, In-Kyu Kang ${ }^{4}$ and Dong Hoon Lee ${ }^{1}$ \\ ${ }^{1}$ Citrus Research Station, National Institute of Horticultural \& Herbal Science R.D.A, Jeju 697-943, Korea \\ ${ }^{2}$ Department of Horticulture, Yeungnam University, Gyeongsan 712-749, Korea \\ ${ }^{3}$ Research Institute for Subtropical Horticulture, Jgiu National University, Jgiu 690-756, Korea \\ ${ }^{4}$ Department. of Environmental Horticulture, Kyungpook National University, Sangiu 742-711, Korea
}

Received February 21, 2011 /Accepted April 10, 2011

\begin{abstract}
The purpose of this study was to evaluate the methods of identifying zygotic seedlings of crosses between 'Morita unshiu' (Citrus. unshiu Marc.) and 'Ponkan' (C. reticulata Blanco). In order to investigate the frequency and position of zygotic seedlings and to determine the efficiency of zygotic seedling identification, random amplified polymorphic DNA (RAPD) and sequence-related amplified polymorphism (SRAP) were performed using $\operatorname{UBC}(9,27,229,230$, and 254) primers and F4/R27, F7/R14, F12/R10, and F44/R62 primer sets, respectively. A total of 37 putative zygotic seedlings out of 55 individuals were selected by RAPD and SRAP. The F7/R14 primer pair showed a screening ability of $45.5 \%(25 / 55)$, whereas the primer UBC27 revealed the highest efficiency of zygotic seedling identification $(50.9 \%, 28 / 55)$. When both UBC27 and F7/R14 were properly used for selection of hybridized seedlings of 'Morita unshiu' (C. unshiu Marc.) and 'Ponkan' (C. reticulata Blanco), screening efficiency was increased to $60 \%(33 / 55)$ for putative zygotic seedlings. Thus, it is possible to select putative hybrid zygotic seedlings in an accurate and effective manner by RAPD and SRAP.
\end{abstract}

Key words : DNA marker, hybrid zygotic seedling, polyembryony, polymorphic bands

\section{Introduction}

Citrus is one of the most important fruit crop currently cultivated worldwide. The species in this genus are trees with persistent leaves, hesperidium fruits, and seeds without endosperm, and often contain two or more nucellar embryos. Most citrus breeding programs around the world have relied mainly on classical breeding strategies for quality improvement. These include making controlled crosses and selecting for superior types. The presence of multiple embryos or nucellar polyembryogenesis is one of the main problems found in citrus breeding. This trait is undesirable since polyembryony can hinder the citrus breeding and improving program by difficult hybrid identification. It has become imperative that efficient methods to separate nucellar from zygotic embryos be developed in order to breed between polyembryonic cultivars. Several studies on various methods towards this goal in several citrus species including

\footnotetext{
*Corresponding author

Tel : +82-64-730-4143, Fax : +82-64-733-9564

E-mail : chocho90@rda.go.kr

${ }^{\dagger}$ These authors contributed equally to this work.
}

'Satsuma' mandarin have been reported. Of them, important techniques are such as: i) thin-layer chromatography [20], ii) isozyme analysis $[5,12,13]$, and iii) gas chromatography [21]. However, these metabolic products are influenced by plant age and environmental conditions, and thus results are usually unreliable for identification purposes [12,22]. Recently, the use of molecular markers has provided a powerful tool for analyzing DNA directly without any influence from the environment or the age of the tissues [19]. It is generally recognized that DNA marker-based selection can be beneficial to the plant breeding field [7], and it has been widely used in many plants $[9,14,16,18]$. In particular, polymerase chain reaction (PCR) has been inexpensively used for genomic DNA analysis. Several PCR marker systems are available with differing in their complexity, reliability, and information generating capacity. These include random amplified polymorphic DNA (RAPD), simple sequence repeat polymorphism (SSR), amplified fragment length polymorphism (AFLP), and a few others $[4,8,14]$. RAPD analysis has been used in citrus for distinguishing nucellars from zygotics $[1,2,3]$. However, researchers recently proposed a new marker-related technique called sequence-related amplified 
polymorphism (SRAP) which combines simplicity, reliability, moderate through-put ratio, and easy sequencing of selected bands [18]. Furthermore, it targets coding sequences in the genome and results in a moderate number of co-dominant markers. SRAP based molecular markers can be applied extensively in genetic linkage map construction [9], genetic diversity analysis [6,11], and for comparative genetics [10] of different species. However, to date, the SRAP molecular markers have not been used in the confirmation of zygotic seedlings in citrus. The objective of this study was to identify zygotic seedlings at an early developmental stage from progeny populations in 'Morita unshiu' (C. unshiu Marc.) and 'Ponkan' (C. reticulata Blanco) using SRAP and RAPD analysis and to examine the efficiency of these DNA-based polymorphic marker systems.

\section{Materials and Methods}

\section{Plant materials and genomic DNA extraction}

Seeds were carefully extracted from mature fruits of the cross between female 'Morita unshiu' (C. unshiu Marc.) and male 'Ponkan' ( $C$. reticulata Blanco). Seedlings were grown in a greenhouse and used for the identification of zygotic seedlings by SRAP and RAPD. Total genomic DNA (gDNA) was extracted from pooled leaves obtained from all seedlings germinating in individual pots. Fifty five samples were obtained. Each seed usually gave rise to 1-3 seedlings gDNA was isolated using the Automated Purification Maxwell 16 system (Promega, Madison, WI, USA), stored at $4^{\circ} \mathrm{C}$ until use.

\section{RAPD analysis}

Each reaction contained $20 \mu \mathrm{l}$ of AccuPower PCR Premix (Bioneer, Korea) [250 $\mu \mathrm{M}$ dNTP, $1.5 \mathrm{mM} \mathrm{MgCl} 2,1.0$ unit Taq DNA polymerase, $10 \mathrm{mM}$ Tris- $\mathrm{HCl}(\mathrm{pH} 9.0), 40 \mathrm{mM} \mathrm{KCl}$, 50 pmole primer and $25 \mathrm{ng}$ template DNA. PCR were performed using a Takara PCR Thermal cycle (Takara, Japan) under the following conditions: i) preheating at $94^{\circ} \mathrm{C}$ for 5min; ii) 40 amplification cycles at $94^{\circ} \mathrm{C}$ for $1 \mathrm{~min}, 38^{\circ} \mathrm{C}$ for $1 \mathrm{~min}$, and $72^{\circ} \mathrm{C}$ for $2 \mathrm{~min}$; and iii) final extension for 10 min at $72^{\circ} \mathrm{C}$. The PCR product was cooled to $4{ }^{\circ} \mathrm{C}$ and analyzed by gel electrophoresis. $1.2 \%$ of agarose gel was stained with $0.5 \mathrm{\mu g} \cdot \mathrm{ml}^{-1}$ of ethidium bromide for visualization of bands.

\section{SRAP analysis}

PCR were set up as for RAPD and gDNA was amplified using the following cycling conditions: i) an initial denaturation at $94^{\circ} \mathrm{C}$ for $5 \mathrm{~min}$; ii) 5 cycles of $1 \mathrm{~min}$ of denaturing at $94^{\circ} \mathrm{C}, 1 \mathrm{~min}$ of annealing at $35^{\circ} \mathrm{C}$, and 2 min elongation at $72^{\circ} \mathrm{C}$; iii) 35 cycles as above except with an annealing temperature of $50^{\circ} \mathrm{C}$; iv) a final elongation incubation for $10 \mathrm{~min}$ at $72^{\circ} \mathrm{C}$ [18]. PCR products were separated as described above.

\section{Results and Discussion}

DNA polymorphic patterns by RAPD and SRAP were developed for identification of putative zygotic seedlings from the cross between 'Morita unshiu' and 'Ponkan' mandarins

293 mature fruits were harvested from the cross of 'Morita unshiu' and 'Ponkan' mandarins and analyzed for early identification of zygotic seedlings. 337 seeds out of 799 seeds obtained from 293 fruits were germinated and grown in a greenhouse. Although young plants from each seed had 1-3 seedlings either from nucellar or zygotic embryos, leaf samples were pooled from all seedlings growing in a pot for preliminary screening. Eventually, a total of 55 samples were screened for the identification of zygotic seedlings using RAPD and SRAP. A total of 199 primers (10-mer) were initially tested using RAPD in order to generate unique polymorphic bands from the putative hybrid seedlings (data not shown). Five primers were subsequently selected based on pollen parent-specific amplified DNA polymorphisms for RAPD, and the primer information is listed in Table 1. The sizes of amplified PCR products also differed among primers; UBC9-1200 bp, UBC27-250 bp, UBC229-1400 bp, UBC230-700 bp, and UBC254-300 bp (Fig. 1A). In case of SRAP, a total of 60 different primer sets were evaluated to obtain polymorphic bands from the parents, but only 4 primer sets were subsequently chosen for SRAP (Table 1). Each primer generated fragments of varying sizes; F4/R27-750 bp, F7/R14-500 bp, F12/R10-470 bp, and F44/R62-600 bp (Fig. 1B). We were able to successfully employ RAPD and SRAP to generate DNA polymorphic patterns for early screening of putative zygotic seedlings from the hybrids of 'Morita unshiu' and 'Ponkan' mandarins. Based on pollen parent-specific band amplification, 37 putative zygotic seedlings were screened using a total of 9 primers/primer sets for either RAPD or SRAP and results were summarized in Table 2. In addition, Fig. 2A panel shows that a distinguishable RAPD amplification pattern, related to the pollen parent, was ob- 
Table 1. The information of five primers out of 199 for RAPD and four sets out of 60 for SRAP are listed. They used for screening of zygotic seedlings from the hybrids between 'Morita unshiu' and 'Ponkan' mandarins

\begin{tabular}{lcl}
\hline & Primer & Sequence $\left(5^{\prime} \rightarrow 3^{\prime}\right)$ \\
\hline \multirow{4}{*}{ RAPD } & UBC9 & CCTGGGTTCC \\
UBC27 & TTTGGGGGGA \\
& UBC229 & CCACCCAGAG \\
& UBC230 & CGTCGCCCAT \\
& UBC254 & CGCCCCCATT \\
& F4 (forward)/R27 & TGAGTCCAAACCGGAAT/ \\
& F7 (reverse) & GACTGCGTACGAATTCGG \\
SRAP & (forward)/R14 & TGAGTCCAAACCGGACG/ \\
& F12 (forward)/R10 & GACTGCGTACGAATTATC \\
& (reverse) & TGAGTCCAAACCGGAGT/ \\
& F44 (forward)/R62 & GACTGCGTACGAATTAGC \\
& (reverse) & TGAGTCCAAACCGGGGT/ \\
\end{tabular}

A

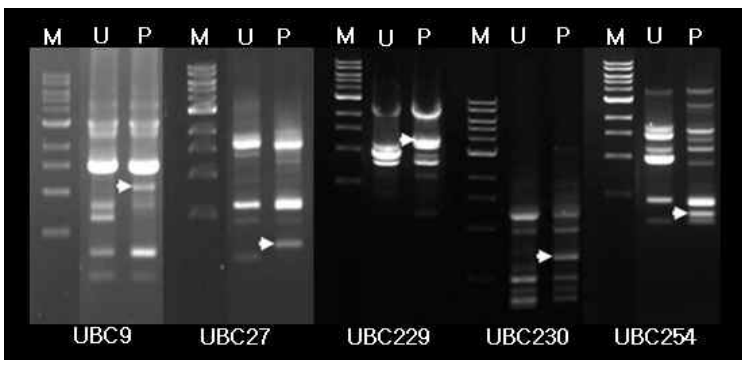

B

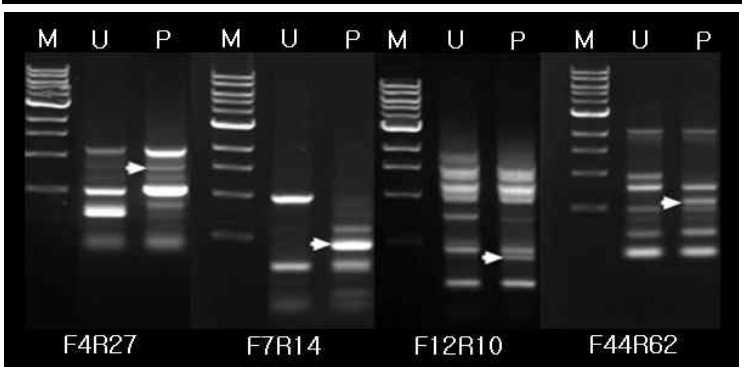

Fig. 1. Parents-related DNA amplification patterns showed polymorphysim by RAPD using five random primers (UBC9, 27, 229, 230, and 254) (A) and by SRAP using four primer sets (F4/R27, F7/R14, F12/R10, and F44/R62) (B). Arrows indicate pollen parent-specific bands that can be used for the identification hybrid seedlings with a zygotic origin. M, $1 \mathrm{~Kb}$ DNA ladder; $\mathrm{U}$, 'Morita unshiu' for female parent; P, 'Ponkan' for male parent.

tained using the UBC27 primer. This primer exhibited 50.9\% (28/55) zygotic identification efficiency. The amplified UBC27-500 bp fragment was not from 'Morita unshiu' but from the male parent 'Ponkan'. UBC9 and UBC230 primers were the second most efficient in identifying zygotic at $34.5 \%(19 / 55)$, while the UBC229 primer showed the lowest efficiency at $20.0 \%(11 / 55)$. When the UBC254 primer was used, the zygotic seedling identification rate was $42.1 \%$. When we used all 5 of these primers, the identification rate of zygotic seedlings was $65.5 \%$ (36/55). From the above results, we conclude that the zygotic seedling identification rate varied depending on primers and their combinations. In addition, SRAP was carried out with the primer pair F7/R14 to complement and validate our RAPD results (Table 2). While F7/R14 showed the highest identification rate of zygotic seedlings at $45.5 \%(25 / 55)$, we had $63.6 \%$ $(35 / 55)$ identification efficiency when using all 4 primers. Fig. 2B panel shows that the SRAP amplification pattern was acquired from nucellar and zygotic seedlings of the hybrids. Arrows indicated pollen parent-related amplification using F7/R14 primers. Zygotic seedlings were distinguished by the presence of a $500 \mathrm{bp}$ band from the male parent. Of the other primer sets, the F44/R62 set was the second most efficient at $34.5 \%(19 / 55)$. The F4/R27 set showed a detection rate of $23.6 \%(13 / 55)$, while the F12/R10 primer combination showed the lowest rate in SRAP analysis at $21.8 \%(12 / 55)$ (Table 2). From RAPD and SRAP results, the rate of zygotic identification in an early stage of seedlings from one seed was $67.3 \%(37 / 55)$ when different primers/primer sets were used. We considered pot numbers 21,31, 35, 36, 39, 46, and 53 as putative zygotic seedlings even though they only amplified by RAPD-UBC27 primer. Similarly, pots 2, 29, 44, 49, and 54 were considered potential zygotic seedlings (although they only amplified by the SRAP primer set F7/R14). It is important to note that there is no significant difference in the rate of detection of zygotic seedlings between RAPD and SRAP when used in early screening from these citrus hybrids. If a pollen parent-specific band was amplified by both UBC27 and F7/R14, the seedlings were considered to have originated from the male parent 'Ponkan'. With nucellar seedlings from a female parent there was no amplification of this pollen-specific band with either UBC27 or F7/R14. As shown in Fig. 2, pot numbers 40, 44, and 49 did not have the male parent-specific band or the $220 \mathrm{bp}$ female parent-specific band. Since Andrade-Rodriguez et al. [1] and Bastianel et al. [3] reported that they considered seedlings without female-specific amplified bands by RAPD analysis to be putative zygotic seedlings, we also considered 40,44 , and 49 to be putative zygotic seedlings. Our results showed that DNA polymorphic patterns could be produced among the 55 samples by both RAPD and SRAP. A pollen-specific band was amplified by both UBC27 and F7/R14 
Table 2. Occurrence and distribution of zygotic seedlings in 'Morita unshiu'and 'Ponkan'. Thirty eight putative zygotic seedlings were confirmed at least once by either RAPD using 5 primers (UBC9, 27, 229, 230, 254) or SRAP using 4 primer sets (F4/R27, F7/R14, F12/R10, F44/R62)

\begin{tabular}{|c|c|c|c|c|c|c|c|c|c|c|c|}
\hline \multirow{2}{*}{$\begin{array}{l}\text { Pot } \\
\text { No. }\end{array}$} & \multirow{2}{*}{$\begin{array}{l}\text { No. of branches } \\
\text { (seedlings) }\end{array}$} & \multirow{2}{*}{$\begin{array}{l}\text { Putative } \\
\text { zygotic } \\
\text { seedlings }\end{array}$} & \multicolumn{9}{|c|}{ Primers } \\
\hline & & & $\begin{array}{c}\text { UBC } \\
9\end{array}$ & $\begin{array}{c}\text { UBC } \\
27\end{array}$ & $\begin{array}{l}\text { UBC } \\
229\end{array}$ & $\begin{array}{l}\text { UBC } \\
230\end{array}$ & $\begin{array}{l}\text { UBC } \\
254\end{array}$ & $\begin{array}{l}\text { F4/ } \\
\text { R27 }\end{array}$ & $\begin{array}{l}\text { F7/ } \\
\text { R14 }\end{array}$ & $\begin{array}{l}\text { F12/ } \\
\text { R10 }\end{array}$ & $\begin{array}{r}\text { F44/ } \\
\text { R62 }\end{array}$ \\
\hline 1 & 2 & $\mathrm{Y}$ & $\mathrm{O}$ & $\mathrm{O}$ & - & $\mathrm{O}$ & - & - & $\mathrm{O}$ & $\mathrm{O}$ & $\mathrm{O}$ \\
\hline 2 & 2 & Y & $\mathrm{O}$ & - & - & - & - & - & $\mathrm{O}$ & $\mathrm{O}$ & $\mathrm{O}$ \\
\hline 3 & 2 & $\mathrm{~N}$ & - & - & - & - & - & - & - & - & - \\
\hline 4 & 2 & $\mathrm{~N}$ & - & & - & - & - & - & - & - & - \\
\hline 5 & 1 & Y & $\mathrm{O}$ & $\mathrm{O}$ & - & $\mathrm{O}$ & $\mathrm{O}$ & - & $\mathrm{O}$ & - & $\mathrm{O}$ \\
\hline 6 & 2 & Y & $\mathrm{O}$ & $\mathrm{O}$ & - & $\mathrm{O}$ & - & - & $\mathrm{O}$ & - & - \\
\hline 7 & 2 & Y & $\mathrm{O}$ & $\mathrm{O}$ & $\mathrm{O}$ & $\mathrm{O}$ & - & - & $\mathrm{O}$ & - & $\mathrm{O}$ \\
\hline 8 & 3 & Y & $\mathrm{O}$ & & - & - & $\mathrm{O}$ & $\mathrm{O}$ & - & $\mathrm{O}$ & $\mathrm{O}$ \\
\hline 9 & 1 & Y & - & $\mathrm{O}$ & - & $\mathrm{O}$ & - & $\mathrm{O}$ & $\mathrm{O}$ & - & - \\
\hline 10 & 1 & $\mathrm{~N}$ & - & - & - & - & - & - & - & - & - \\
\hline 11 & 2 & $\mathrm{~N}$ & - & - & - & - & - & - & - & - & - \\
\hline 12 & 2 & Y & $\mathrm{O}$ & $\mathrm{O}$ & - & - & $\mathrm{O}$ & $\mathrm{O}$ & $\mathrm{O}$ & - & $\mathrm{O}$ \\
\hline 13 & 2 & $\mathrm{~N}$ & - & - & - & - & - & - & - & - & - \\
\hline 14 & 1 & $\mathrm{~N}$ & - & - & - & - & - & - & - & - & - \\
\hline 15 & 1 & Y & $\mathrm{O}$ & $\mathrm{O}$ & - & - & - & - & $\mathrm{O}$ & - & - \\
\hline 16 & 3 & $\mathrm{~N}$ & - & - & - & - & - & - & - & - & - \\
\hline 17 & 2 & $\mathrm{~N}$ & - & - & - & - & - & - & - & - & - \\
\hline 18 & 1 & Y & - & $\mathrm{O}$ & - & - & $\mathrm{O}$ & $\mathrm{O}$ & $\mathrm{O}$ & $\mathrm{O}$ & $\mathrm{O}$ \\
\hline 19 & 2 & $\mathrm{~N}$ & - & - & - & - & - & - & - & - & - \\
\hline 20 & 2 & $\mathrm{~N}$ & - & - & - & - & - & - & - & - & - \\
\hline 21 & 1 & Y & - & $\mathrm{O}$ & $\mathrm{O}$ & - & - & - & - & $\mathrm{O}$ & - \\
\hline 22 & 1 & $\mathrm{~N}$ & - & - & - & - & - & - & - & - & - \\
\hline 23 & 2 & Y & - & $\mathrm{O}$ & - & $\mathrm{O}$ & - & - & $\mathrm{O}$ & $\mathrm{O}$ & $\mathrm{O}$ \\
\hline 24 & 3 & $\mathrm{~N}$ & - & - & - & - & - & - & - & - & - \\
\hline 25 & 2 & $\mathrm{~N}$ & - & - & - & - & - & - & - & - & - \\
\hline 26 & 1 & $\mathrm{~N}$ & - & - & - & - & - & - & - & - & - \\
\hline 27 & 2 & Y & - & $\mathrm{O}$ & - & $\mathrm{O}$ & $\mathrm{O}$ & - & $\mathrm{O}$ & - & $\mathrm{O}$ \\
\hline 28 & 2 & $\mathrm{~N}$ & - & & - & - & - & - & - & - & - \\
\hline 29 & 1 & $Y$ & - & - & $\mathrm{O}$ & - & $\mathrm{O}$ & - & $\mathrm{O}$ & $\mathrm{O}$ & - \\
\hline 30 & 1 & $Y$ & $\mathrm{O}$ & $\mathrm{O}$ & $\mathrm{O}$ & $\mathrm{O}$ & $\mathrm{O}$ & $\mathrm{O}$ & $\mathrm{O}$ & - & - \\
\hline 31 & 2 & $Y$ & $\mathrm{O}$ & $\mathrm{O}$ & - & $\mathrm{O}$ & - & - & - & - & - \\
\hline 32 & $\overrightarrow{1}$ & $Y$ & - & - & - & - & - & $\mathrm{O}$ & - & - & - \\
\hline 33 & 2 & Y & $\mathrm{O}$ & $\mathrm{O}$ & $\mathrm{O}$ & 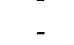 & $\mathrm{O}$ & - & - & - & $\mathrm{O}$ \\
\hline 34 & 3 & $Y$ & - & $\mathrm{O}$ & $\mathrm{O}$ & $\mathrm{O}$ & $\mathrm{O}$ & - & $\mathrm{O}$ & - & $\mathrm{O}$ \\
\hline 35 & 1 & $Y$ & - & $\mathrm{O}$ & - & - & - & - & - & - & $\mathrm{O}$ \\
\hline 36 & 2 & Y & $\mathrm{O}$ & $\mathrm{O}$ & - & $\mathrm{O}$ & $\mathrm{O}$ & - & - & - & - \\
\hline 37 & 2 & Y & - & $\mathrm{O}$ & - & - & - & - & $\mathrm{O}$ & - & - \\
\hline 38 & 1 & Y & $\mathrm{O}$ & $\mathrm{O}$ & - & $\mathrm{O}$ & $\mathrm{O}$ & - & O & - & $\mathrm{O}$ \\
\hline 39 & 2 & $Y$ & $\mathrm{O}$ & $\mathrm{O}$ & $\mathrm{O}$ & - & - & $\mathrm{O}$ & - & $\mathrm{O}$ & - \\
\hline 40 & 1 & $Y$ & $\mathrm{O}$ & - & - & $\mathrm{O}$ & $\mathrm{O}$ & $\mathrm{O}$ & - & - & - \\
\hline 41 & 2 & $\mathrm{~N}$ & - & - & - & - & - & - & - & - & - \\
\hline 42 & 1 & Y & - & $\mathrm{O}$ & - & - & - & $\mathrm{O}$ & $\mathrm{O}$ & - & $\mathrm{O}$ \\
\hline 43 & 1 & $Y$ & - & $\mathrm{O}$ & $\mathrm{O}$ & - & - & $\mathrm{O}$ & $\mathrm{O}$ & - & - \\
\hline 44 & 1 & $Y$ & - & - & $\mathrm{O}$ & $\mathrm{O}$ & - & $\mathrm{O}$ & $\mathrm{O}$ & $\mathrm{O}$ & - \\
\hline 45 & 2 & $Y$ & $\mathrm{O}$ & - & - & - & $\mathrm{O}$ & - & - & $\mathrm{O}$ & - \\
\hline 46 & 1 & Y & - & $\mathrm{O}$ & - & $\mathrm{O}$ & - & $\mathrm{O}$ & - & - & - \\
\hline 47 & 2 & $\mathrm{~N}$ & - & - & - & - & - & - & - & - & - \\
\hline 48 & 1 & $\mathrm{~N}$ & - & - & - & - & - & - & - & - & - \\
\hline 49 & 1 & $Y$ & $\mathrm{O}$ & 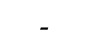 & - & $\mathrm{O}$ & - & - & $\mathrm{O}$ & $\mathrm{O}$ & - \\
\hline 50 & 3 & $Y$ & 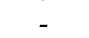 & $\mathrm{O}$ & $\mathrm{O}$ & 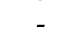 & $\mathrm{O}$ & - & $\mathrm{O}$ & - & $\mathrm{O}$ \\
\hline 51 & 2 & $Y$ & $\mathrm{O}$ & $\mathrm{O}$ & - & - & $\mathrm{O}$ & - & $\mathrm{O}$ & - & $\mathrm{O}$ \\
\hline 52 & 3 & $Y$ & - & $\mathrm{O}$ & - & $\mathrm{O}$ & - & - & $\mathrm{O}$ & - & - \\
\hline 53 & 2 & $Y$ & $\mathrm{O}$ & $\mathrm{O}$ & $\mathrm{O}$ & . & - & - & - & - & $\mathrm{O}$ \\
\hline 54 & 1 & $Y$ & - & - & - & $\mathrm{O}$ & - & $\mathrm{O}$ & $\mathrm{O}$ & - & $\mathrm{O}$ \\
\hline 55 & 2 & Y & - & $\mathrm{O}$ & - & $\mathrm{O}$ & $\mathrm{O}$ & - & $\mathrm{O}$ & $\mathrm{O}$ & $\mathrm{O}$ \\
\hline & $\begin{array}{l}\text { putative zygotic } \\
\text { seedlings }\end{array}$ & 37 & 19 & 28 & 11 & 19 & 16 & 13 & 25 & 12 & 19 \\
\hline
\end{tabular}

Y: putative zygotic seedlings showing amplification of a pollen-specific band by at least one primer/set of primers.

$\mathrm{N}$ : putative nucellar seedlings which have no pollen-specific amplification by any primers. O: male parent-specific amplification by a primer, -: no amplification 
A

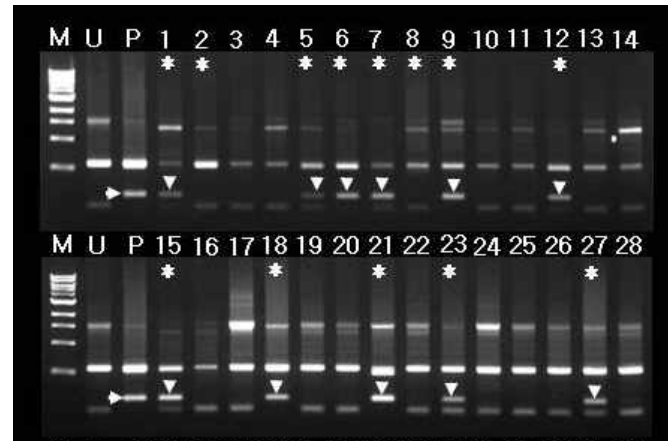

B

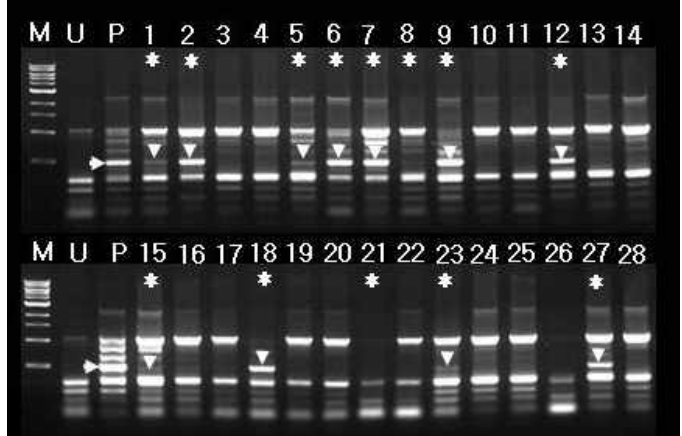

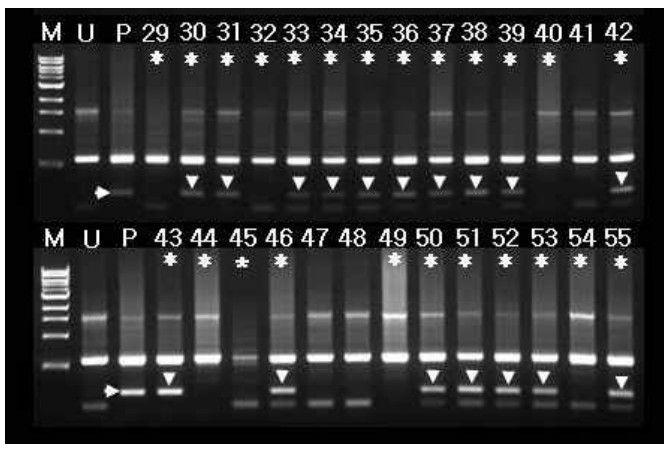

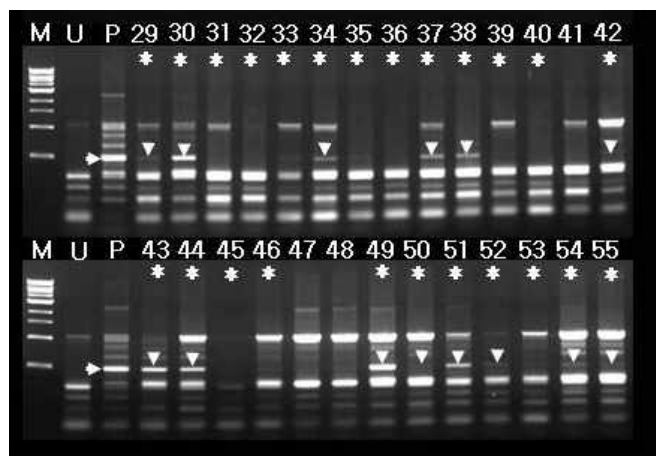

Fig. 2. Putative zygotic seedlings were identified by RAPD with UBC27 (A) and SRAP with F7/R14 (B). 55 hybrid populations of 'Morita unshiu' and 'Ponkan' were screened for early identification of putative zygotic seedlings. Arrows indicate a 250bp in upper panel (28 putative zygotic seedlings) and a $500 \mathrm{bp}$ in lower panel (25 putative zygotic seedlings) for pollen specific bands. M, 1Kb DNA ladder; U, 'Morita unshiu' for female parent; P, 'Ponkan' for male parent; *, 37 putative zygotic seedlings confirmed at least once by either RAPD with 5 primers (UBC9, 27, 229, 230, 254) or SRAP with 4 primers (F4/R27, F7/R14, F12/R10, F44/R62).

$(\mathrm{O}, \mathrm{O})$ in 20 cases. Meanwhile, there were 22 cases where no amplification occurred when using either primer/primer set $(X, X)$. There were 8 cases in which DNA could only be amplified by $\operatorname{UBC} 27(\mathrm{O}, \mathrm{X})$, and 5 instances in which DNA could only be amplified by the primer set F7/R14 (X, O) (Table 2, Fig. 2).

Early screening of putative zygotic seedlings from hybrid mandarin citrus 'Morita unshiu' and 'Ponkan' was possible by RAPD and SRAP

In order to select zygotic seedlings from mixed leaf samples, eight sets were randomly selected amongst 37 individuals and screened for the presence of any male parent-related amplified bands using the UBC27 primer for RAPD and the F7/R14 primer set for SRAP analysis (Fig. 3). Pot numbers $1,12,23,34$, and 50 had the $(\mathrm{O}, \mathrm{O})$ pattern, pot 8 had the $(X, X)$ pattern, 39 had the $(O, X)$ pattern, and pot 2 the $(X, O)$ pattern. Each pot had 2-3 hybrid seedlings, and gDNA was isolated from each seedling in a pot. The samples were amplified for zygotic identification using UBC27 and F7/R14 primers (Fig. 3). These results confirmed

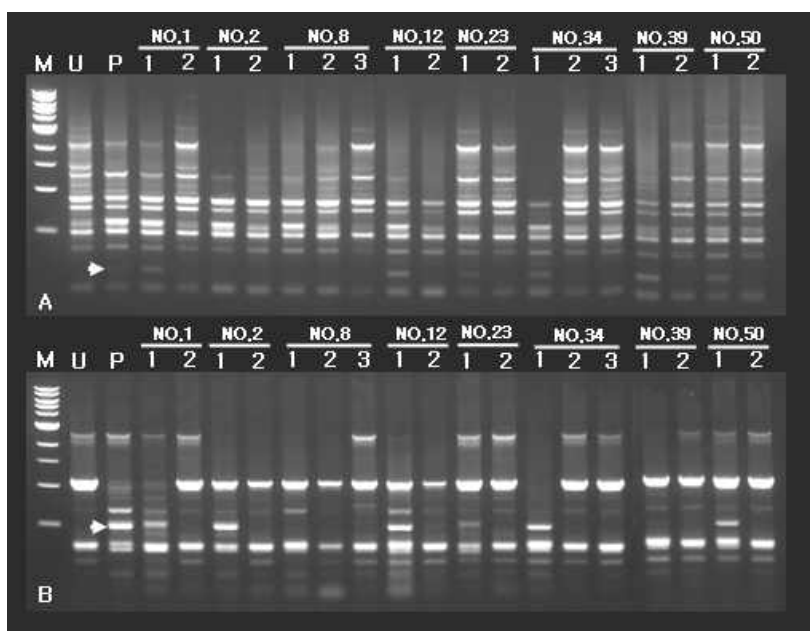

Fig. 3. Identification and separation of zygotic seedlings from polyembryonic seedlings of 'Morita unshiu' and 'Ponkan' using RAPD and SRAP. A, RAPD using the UBC27 primer (250 bp); B, SRAP using the F7/R14 primers (500 bp). Seedlings in each pot were screened individually for zygotic seedling identification. Arrows indicate a pollen specific band (250 bp using UBC27 and 500 bp using F7/R14). M, 1 Kb DNA ladder; U, 'Morita unshiu' for female parent; $\mathrm{P}$, 'Ponkan' for male parent. 
the previous data, that it was possible to select zygotic seedlings among 2-3 seedlings from polyembryonic citrus. Recently, many studies attempting to develop zygotic seedling selection markers have been performed using AFLP, SSR, etc $[14,16,17]$. We also tried to find a male parent-specific DNA marker for early identification of putative zygotic seedlings from hybrids of 'Morita unshiu' and 'Ponkan' by RAPD and SRAP. It was determined that RAPD with the UBC27 primer and SRAP with the F7/R14 primer set were the most efficient approaches for selection and identification of putative zygotic seedlings from hybrid seedlings. Depending on the parents selected, various levels of zygotic seedlings have also been observed in the progeny. According to Yun et al. [22] 20 out of 149 (13.4\%) seedlings from the cross of 'Miyagawa unshiu' and 'Ponkan' mandarins were zygotic. Bastianel et al. [3] reported that 54 plants of a population of $202(26.7 \%)$ following a cross of 'King' and 'Montenegrina' were zygotic. Recently, Rao et al. [15] identified $26.64 \%$ zygotic seedlings from crossing mandarin (C. reticulata) $\times$ pummelo ( $C$. maxima) species using $\mathrm{RAPD}$ analysis. In this study, we could identify putative zygotic seedlings in a early developmental stages with $20-50 \%$ efficiency by performing RAPD and SRAP with various primers. When we combined these primers for screening, the identification efficiency was increased to $67.3 \%(37 / 55)$. This does not mean that we had a high percentage of sexual progeny from artificial fertilization between 'Morita unshiu' and 'Ponkan'. It is more likely due to the small statistical populations (55) for this experiment compared to other studies. However, RAPD-UBC27 and SRAP-F7/R14 can be used as a fast, primary screening technique for identifying putative zygotic seedlings in the cross of 'Morita unshiu' and 'Ponkan', and it is plausible to expect improvement of accuracy of early selection in a citrus breeding program.

\section{Acknowledgment}

This research was supported by Yeungnam University research grants in 2008 (208-A-235-136).

\section{References}

1. Andrade-Rodriguez, M., A. Villegas-Monter, C. G. Carrillo-Castaneda, and A. Garcia-Velazquez. 2004. Polyembryony and identification of Volkamerian lemon zygotic and nucellar seedlings using RAPD. Pesq Agropec. Bras. Brasilia 39, 551-559.
2. Andrade-Rodriguez, M., A. Villegas-Monter, A. Gutierrez-Espinosa, C. G. Carrillo-Castaneda, and A. Garcia-Velazquez. 2005. Polyembryony and RAPD markers for identification of zygotic and nucellar seedlings in Citrus. Agrociencia 39, 371-383.

3. Bastianel, B., S. F. Schwardz, C. H. D. Filho, L. L. Lin, M. Machado, and O. C. Koller. 1998. Identification of zygotic and nucellar tangerine seedlings (Citrus spp.) using RAPD. Genet. Mol. Biol. 21, 123-127.

4. Birren, B. and E. Lai. 1996. Non-mammalian genome analysis : a practical guide. pp. 75-134, Academic Press Inc., New York.

5. Elisiario, P. J., E. M. Justo, and J. M. Leitao. 1999. Identification of mandarin hybrids by isozyme and RAPD analysis. Scientia Horticulturae 81, 287-299.

6. Ferriol, M. B., B. Pico, and F. Nuez. 2003. Genetic diversity of a germplasm collection of Cucurbita pepo using SRAP and AFLP markers. Theor. Appl. Genet. 107, 271-282.

7. Hospital, F., C. Chevalet, and P. Mulsant. 1992. Using markers in gene introgression breeding programs. Genetics 132, 1199-1210.

8. Lee, M. 1995. DNA markers and plant breeding programs. Adv. Agron. 55, 265-344.

9. Li, G., and C. F. Quiros. 2001. Sequence-related amplified polymorphism (SRAP), a new marker system based on a simple PCR reaction: its application to mapping and gene tagging in Brassica. Theor. Appl. Genet. 103, 455-461.

10. Li, G., M. Gao, B. Yang, and C. F. Quiros. 2003. Gene for gene alignment between the Brassica and Arabidopsis genomes by direct transcriptome mapping. Theor. Appl. Genet. 107, 168-180.

11. Lin, Z. X., X. L. Zhang, and Y. C. Nie. 2004. Evaluation of application of a new molecular marker SRAP on analysis of F2 segregation population and genetic diversity in cotton. Acta Genetica Sinica 31, 622-626.

12. Luro, F., F. Laigret, J. M. Bove, and P. Ollitrault. 1995. DNA amplified fingerprinting, a useful tool for determination of genetic origin and diversity analysis in Citrus. HortScience 30, 1063-1067.

13. Moon, D. K. and K. C. Ko. 1991. Isozymes as genetic markers in Citrus growing in Cheju and their use for identification of nucellar and zygotic seedlings. J. Korean Soc. Hort. Sci. 32, 59-65.

14. Oliveira, A. C., A. N. Garcia, M. Cristofani, and M. A. Machado. 2002. Identification of citrus hybrids through the combination of leaf apex morphology and SSR markers. Euphytica 128, 397-403.

15. Rao, M. N., J. R. Soneji, C. Chen, S. Huang, and F. G. Gmitter Jr. 2008. Characterization of zygotic and nucellar seedlings from sour orange-like citrus rootstock candidates using RAPD and EST-SSR markers. Tree Genet. Genomes 4, 113-124.

16. Ruiz, C., M. Paz Breto, and M. J. Asins. 2000. A quick methodology to identify sexual seedlings in citrus breeding programs using SSR markers. Euphytica 112, 89-94.

17. Scarano, M. T., N. Tusa, L. Abbate, S. Lucretti, L. Nardi, 
and S. Ferrante. 2003. Flow cytometry, SSR and modified AFLP markers for the identification of zygotic plantlets in backcrosses between 'Femminello' lemon cybrids ( $2 \mathrm{n}$ and $4 \mathrm{n}$ ) and a diploid clone of 'Femminello' lemon (Citrus limon L. Burm. F.) tolerant to mal secco disease. Plant Science 164, 1009-1017.

18. Sun, S. J. W. Gao, S. Q. Lin, J. Zhu, B. G. Xie, and Z. B. Lin. 2006. Analysis of genetic diversity in Ganoderma population with a novel molecular marker SRAP. Appl. Microbiol. Biotechnol. 72, 537-543.

19. Tansksley, S. D., N. D. Young, A. H. Paterson, and M. W. Bonierbale. 1989. RFLP mapping in plant breeding: new tool for an old science. Biotechnology 7, 257-264.

20. Tatum, J. H., C. J. Hearn, and R. E. Berry. 1978. Characterization of citrus cultivar by chemical differentiation. J. Amer. Soc. Hort. Sci. 103, 492-496.

21. Weinbaum, S. A., E. Cohen, and P. Spiegel-Roy. 1982. Rapid screening of satsuma mandarin progeny to distinguish nucellar and zygotic seedling. HortScience 17, 239-240.

22. Yun, J. U., H. B. Yang, Y. H. Jung, S. H. Yun, K. S. Kim, C. S. Kim, and K. J. Song. 2007. Identification of zygotic and nucellar mandarin seedlings using randomly amplified polymorphic DNA. Hort. Environ. Biotechnol. 48, 171-175.

\section{초록 : RAPD와 SRAP 방법을 이용한 '성전온주'(C. unshiu Marc.)와 '병감'(C. reticulate Blanco) 교잡실생 식별 \\ 윤수현 ${ }^{1+} \cdot$ 문용선 ${ }^{2+} \cdot$ 진성범 ${ }^{3} \cdot$ 강인규 $\cdot$ 이동훈 ${ }^{1}$ \\ ( ${ }^{1}$ 국립원예특작과학원 감귤시험장, ${ }^{2}$ 영남대학교 원예학과, ${ }^{3}$ 제주대학교 아열 대원예연구소, ${ }^{4}$ 경북대학교 환경 원예학과)}

감귤 '성전온주'(C. unshiu Marc)와 '병감'(C. reticulate Blanco)을 교배하여 얻은 다배성종자에서 교잡실생을 생 육초기에 효과적으로 식별할 수 있는 방법 얻고자 PCR 기법에 바탕을 둔 RAPD와 SRAP 방법을 수행하였다. $\mathrm{UBC}(9,27,229,230,254)$ 프라이머와 SRAP (F4/R27, F7/R14, F12/R10, F44/R62) 프라이머 조합들을 사용하여 55 개의 교배종자에서 얻은 실생들을 조사한 결과 37개의 종자에서 교잡실생을 식별할 수 있었다. F7/R14프라이 머 조합에서는 $45.5 \%$ (25/55)의 교잡실생을 식별할 수 있었고, UBC27 프라이머에서는 50.9\% (28/55)의 식별효율 을 보였다. 성전온주와 병감의 교배종자에서 UBC27 프라이머와 F7/R14 프라이머조합을 동시에 적용하였을 때 에는 33 개 $(60 \%, 33 / 55)$ 의 종자에서 교잡실생을 식별할 수 있었다. 따라서 RAPD와 SRAP를 이용하였을 때 다배 성 종자에서 교잡실생을 생육초기에 효율적으로 식별할 수 있었다. 